\title{
ALIENASI TOKOH UTAMA DALAM NOVEL POL KARYA PUTU WIJAYA
}

\author{
Anwar Efendi \\ FBS Universitas Negeri Yogyakarta
}

\begin{abstract}
Abstrak
This research objective is to describe two things, namely (1) the manifestations of alienation and (2) characterization elements employed to describe human alienation in Pol, a novel by Putu Wijaya. These two things are related to the worldview adopted by Putu Wijaya as a writer in response to the sociohistorical condition in society.

The source of the data in this study was Putu Wijaya's Pol (the first impression, 1987). The data were collected through reading and recording. The data analysis covered two aspects, namely (1) the structural aspect, and (2) the genetic aspect of the literary work, the writer's worldview. The validity was assessed through semantic validity and the reliability was assessed by reading and rereading (intrarater reliability).

On the basis of the research findings and analysis, some inferences can be made. First, alienation in $\mathrm{Pol}$ on the basis of its manifestations can be classified into three categories, namely (a) loneliness, (b) spiritual emptiness, and (c) disappointment. Second, characters' alienation symptoms are expressed through characterization elements, comprising (a) the writer' s description of characters, (b) characters' thoughts, (c) characters' actions, and (d) minor characters' reactions to the main character. A literary work as a life model or an alternative world is always related to the real life. In the novel, Putu Wijaya posits himself as a photographer of the society's life.
\end{abstract}

Key words: alienation, disappointment, loneliness, and spiritual emptiness

\section{A. Pendahuluan}

\section{Latar Belakang}

Ada berbagai cara untuk menjabarkan kondisi manusia dan dunianya. Salah satunya melalui karya sastra. Karya sastra dan kehidupan merupakan dua fenomena sosial yang saling melengkapi dalam kedirian mereka sebagai sesuatu yang eksistensial (Suyitno, 1996: 3). Ini berarti bahwa karya sastra dan kehidupan nyata selain memiliki otonomi tersendiri, juga keduanya memiliki hubungan timbal balik.

Membicarakan keterkaitan antara sastra dan kehidupan Rudolf Unger (dalam Wellek dan Warren, 1990:141) menyatakan, sastra bukanlah filsafat yang diterjemahkan dalam bentuk pencitraan, melainkan ekspresi atau sikap umum terhadap kehidupan. Lebih lanjut Unger menjelaskan, permasalahan yang digarap sastra antara lain (1) masalah nasib, yakni hubungan antara kebabasan dan keterpaksaan, semangat manusia dan alam, (2) masalah keagamaan, (3) masalah mitos dan ilmu gaib, (4) masalah yang menyangkut konsepsi manusia, hubungan manusia dengan kematian dan konsep cinta, dan (5) masalah masyarakat dan keluarga.

Merujuk uraian di atas dapat disimpulkan bahwa persoalan zaman dan ke- 
masyarakatan dari kurun waktu tertentu berpengaruh pada pemilihan tematema yang diungkapkan para sastrawan dalam karya-karyanya. Pergeseran persoalan zaman dan kemasyarakatan akan menyebabkan pergeseran pemilihan tema. Demikian pula halnya dengan persoalan zaman dan kemasyarakatan saat ini, terutama menyangkut modernisasi yang ditandai dengan kemajuan teknologi. Persoalan tersebut juga tak luput dari pencermatan para sastrawan yang pada akhirnya menjadi aspek tema yang dituangkan dalam karya sastra.

Kenyataan membuktikan bahwa kehidupan modern yang ditandai dengan kemajuan teknologi telah banyak memberikan manfaat bagi kehidupan manusia. Manusia semakin lama semakin terikat dengan teknologi. Teknologi tidak lagi berhadapan dengan manusia, tetapi sudah terintegrasi dengan manusia. Dalam kondisi demikian itulah manusia akan menjadi terkungkung oleh kemajuan itu sendiri.

Kemajuan teknologi pada awalnya membuat efisiensi dalam kehidupan manusia. Perkembangan selanjutnya, teknologi justru menenggelamkan manusia dalam suatu rutinitas dan otomatisasi kerja yang diciptakan. Keadaan itulah yang menjadi salah satu penyebab manusia terpisah dari sesama atau dunia luar dan akhirnya mengalami keterasingan (alienasi). Manusia tidak lagi hidup secara bebas dengan lingkungannya tetapi secara berangsur-angsur telah dikelilingi oleh teknik, organisasi, dan sistem yang diciptakan sendiri. Manusia mulai terkuasai oleh kekuatan-kekuatan tersebut sehingga menjadi tergantung dan lemah. Dalam keadaan ini manusia tidak lagi menjadi subjek yang mandiri tetapi telah mengalami detotalisasi dan dehumanisasi (Poespowardojo, 1989).

Kondisi yang digambarkan tersebut merupakan gejala sosial yang umum terjadi pada masyarakat modern. Darma (1995: 134) menyebut keterasingan (alienasi) pada awalnya merupakan gejala sosial dalam masyarakat modern. Keterasingan itu sendiri merupakan salah satu tema yang ada dalam telaah filsafat eksistensialisme. Selain tema keterasingan dalam eksistensialisme dibahas pula tentang (1) subjektivitas, (2) kebebasan, (3) kegagalan, dan (4) kematian (Koeswara, 1987: 9; Hasan, 1992: 7).

Manusia dengan segala keterasingannya itulah yang ditampilkan dalam novel-novel Putu Wijaya. Kuntowijoyo (1984:131) menyebut karya Putu Wijaya merupakan wujud dari karya sastra eksistensialis. Sastra eksistensialis yang bermula dari filsafat eksistensialisme, menghadapkan individu dengan masyarakatnya dalam sebuah pertarungan eksistensial. Dalam hal ini, individu telah disudutkan oleh masyarakatnya dan ia menjadi bagian yang dengan siasia menegakkan eksistensinya dengan segala macam cara.

Berdasarkan uraian di atas, menarik untuk dikaji bagaimana upaya Putu Wijaya memotret realitas manusia modern dengan segala permasalahan yang ada. Salah satunya adalah permasalahan yang menyangkut identitas kedirian manusia baik sebagai individu maupun bagian dari lingkungan sosial.

\section{Tujuan Penelitiam}

Permasalahan dalam penelitian berkaitan dengan fenomena alienasi yang dialami tokoh utama dalam novel Pol, yang mencakup wujud alienasi dan cara pengarang menampilkan gambaran alienasi. Dengan demikian, tujuan penelitian ini adalah (a) mendeskripsikan wujud alienasi manusia dalam novel Pol karya Putu Wijaya, dan (b) mendeskripsikan unsur penokohan yang digunakan untuk menggambarkan alienasi manusia dalam novel Pol karya Putu Wijaya 


\section{Landasan Cerita}

\section{a. Konsep Dasar Eksistensialisme}

Secara etimologis, eksistensialisme berasal dari kata "ex" yang berarti keluar dan "sistere" yang berarti berdiri (Dagun, 1990: 19). Konsep ini menekankan bahwa sesuatu tidak ada. Sementara itu, Drijarkara (1995: 55) menjelaskan bahwa eksistensialisme berasal dari kata "eks" yang artinya keluar dan "sistensia" yang artinya menempatkan diri. Dengan eksistensi berarti manusia berdiri sendiri dengan keluar dari diri sendiri.

Eksistensialisme merupakan aliran filsafat yang memandang segalagalanya dengan berpangkal kepada eksistensi, yaitu cara berada manusia di dunia ini. Hal itu ditentukan oleh adanya keutuhan jasmani dan rohani manusia yang menjadikan dirinya sebagai subjek yang bebas dan bertanggung jawab. Permasalahan utama yang menjadi perhatian para pemikir eksitensialis adalah keberadaan manusia. Meskipun terdapat beberapa perbedaan pandangan mengenai konsep dasar eksistensialisme, pada umumnya pokok-pokok pikiran yang diperbincangkan mempunyai kesamaan. Pokok-pokok pembicaraan tersebut diwadahi dalam bingkai tema-tema eksistensialisme. Terdapat lima tema utama dalam filsafat eksistensialisme, yaitu (1) subjektivitas, (2) kebebasan, (3) kegagalan, (4) alienasi (keterasingan), dan (5) kematian.

Berkaitan dengan tema alienasi, para eksistensialis memandang bahwa manusia modern adalah manusia yang hidup dalam keterasingan. Dalam keterasinganya, segala pikiran, sikap, ataupun tindakan akan diikuti oleh kesepian, kekosongan jiwa, maupun kecemasan. Hal itu terjadi karena individu mengalami keterputusan dengan dirinya sendiri, sesamanya, maupun dengan dunia luar. Apabila manusia tidak dapat mengatasi kekuatan-kekuatan di luar dirinya, ia akan menemukan dirinya tidak berdaya, tidak berharga, ataupun kehilangan gairah hidup (Koeswara, 1987:16).

\section{b. AlienasidalamKehidupanManusia}

Dalam pandangan para pemikir eksistensialis, manusia modern semakin jauh meninggalkan hakikat manusia itu sendiri. Setiap orang hanya mengejar kemajuan, menikmati segala fasilitas teknologi. Akan tetapi, lambat laun manusia menjadi terbelenggu oleh kemajuan itu sendiri sehingga tidak mengenal lagi hal-hal yang bersifat manusiawi (Dagun, 1990:109). Lunturnya nilai-nilai manusiawi telah menggiring manusia pada suatu kondisi keterasingan. Secara filosofis, keterasingan manusia menunjukkan adanya pikiran, sikap, ataupun tindakan yang menjurus pada goyahnya eksistensi manusia.

Sartre (Koeswara, 1987: 24) mengatakan bahwa keterasingan merupakan akibat dari adanya konflik yang ditimbulkan oleh relasi-relasi antarmanusia. Pada sisi lain, Sartre juga menyebutkan bahwa keterasingan manusia adalah keterasingan bagi tubuhnya sendiri yang ditemui pada orang lain. Artinya, seolah-olah orang lain merampas tubuh kita kemudian menyusun dunianya sendiri dengan menyertakan ketubuhan kita sebagai bagian dari dunianya. Keterasingan antara diri kita dan tubuh sendiri membuat kehilangan penguasaan terhadap tubuh. Hal itu dapat ditemui pada gerak-gerik tertentu yang terobjektifkan. Dari berbagai pandangan di atas, dapat disimpulkan bahwa keterasingan merupakan keterputusan manusia dengan dirinya sendiri maupun dunia luar. Keterasingan tampak pada pola pikir, sikap, dan tindakan dalam menghadapi persoalan hidup. Dalam kondisi demikian, manusia akan menemukan dirinya tidak berdaya, tidak berharga, dan kehilangan gairah hidup. Yang di- 
maksud dengan keterputusan manusia dengan dirinya sendiri, adalah situasi ketika manusia kehilangan kontak dengan dirinya sendiri karena persoalan yang berasal dari diri sendiri. Sementara itu, keterputusannya dengan dunia luar, yakni manusia telah kehilangan kontak dengan dunia luar atau sesamanya.

\section{c. Karya Sastra sebagai Dokumen So- sial}

Sebagai hasil kreativitas pengarang, karya sastra tidak akan terlepas dari masyarakat, sebagaimana pengarang yang menjadi bagian dari masyarakat. Dalam kegiatan penelaahan sastra dan masyarakat, pendekatan yang umum digunakan adalah mempelajari sastra sebagai dokumen sosial, sebagai potret kenyataan. Sebagai dokumen sosial, sastra digunakan untuk menguraikan ikhtisar sejarah sosial (Wellek dan Warren, 1990:112).

Karya sastra bukan hanya sekedar permainan imajinasi, melainkan merupakan rekaman tata cara masyarakat sezamannya sebagai perwujudan dari niat tertentu. Novel adalah cermin yang bisa dibawa ke manapun dan paling cocok untuk memantulkan segala aspek kehidupan dan alam. Sebagai gambaran struktur sosial, yang terdapat dalam novel adalah gambaran masalah masyarakat secara umum ditilik dari sudut lingkungan tertentu, yang akhirnya mengarah pada sifat yang universal (Damono, 1984: 19).

Karya sastra yang baik adalah karya sastra yang mampu menciptakan kembali rasa kehidupan, bobot dan suasananya mampu menciptakan kembali keseluruhan kehidupan yang dihayati sendiri. Sastra yang baik mampu menciptakan kemendasaran makna kehidupan manusia. Dari hasil rekaan pengarang, dunia kenyataan dapat direkam dengan kreasi dan imajinasi. Kedudukan karya sastra sebagai dokumen sosial dikaitkan dengan situasi dan kondisi yang terjadi pada saat karya sastra tersebut diciptakan. Situasi dam kondisi masyarakat akan ikut mempengaruhi konsep pemikiran pengarang. Agar karya sastra tidak terjebak pada kondisi sebagai catatan sejarah semata-mata, pada saat penciptaannya pengarang tidak begitu saja menjiplak realitas kehidupan.

\section{d. Karya Sastra sebagai Ekspresi Pan- dangan Dunia Pengarang}

Sesuai dengan konsep dasar teori dan pendekatan strukturalisme genetik, keberadaan karya sastra dipandang sebagai ekspresi pandangan dunia kelompok sosial pengarang dalam merespon kondisi sosial historis yang terjadi dalam masyarakat. Struktur karya sastra, seperti novel yang terdiri atas tokoh, latar, alur, juga tema yang sifatnya imajinatif dianggap sebagai dunia imajiner untuk mengekspresikan pandangan dunia kelompok sosial pengarang.

Dalam kerangka strukturalisme genetik, karena karya sastra merupakan ekspresi dari pandangan dunia, maka pandangan dunia menentukan struktur karya sastra. Pandangan dunia, sebagai totalitas dari cara berpikir, merasa, dan bertindak dari suatu kelompok sosial tertentu ketika berhadapan dengan persoalan sosial historis tertentu yang terjadi dalam realitas. Karya tersebutlah yang mampu mengekepresikan kondisi manusia yang universal dan dasar (Goldman, 1973: 311). Oleh karena itu, kebesaran suatu karya sastra sebenarnya menjadi syarat bagi karya sastra yang sesuai untuk dikaji dengan pendekatan strukturalisme genetik. Kebesaran karya sastra menurut Goldman (1973: 312) berkaitan dengan fakta estetis. Fakta estetis tersebut dilihat dari (a) hubungan antara pandangan dunia sebagai kenyataan yang dialami dan alam 
ciptaan pengarang, dan (b) hubungan antara alam ciptaan pengarang tersebut dengan alat-alat kesastraan tertentu seperti sintaksis, gaya, dan citraan yang digunakan pengarang untuk mengekpresikannya.

\section{B. Metode Penelitian}

Sumber data dalam penelitian ini adalah novel Pol karya Putu Wijaya, cetakan pertama, tahun 1987. Dengan demikian data penelitian ini berupa data verbal yang terdapat dalam novel Pol, yang dapat menjelaskan keberadaan alienasi dan unsur-unsur penokohan yang digunakan untuk menggambarkan adanya alienasi. Pengumpulan data dalam penelitian ini dilakukan dengan cara pembacaan dan pencatatan (baca catat).

Analisis data dilakukan mencakup dua aspek, yaitu (1) aspek struktural dan (2) aspek genetik karya sastra. Analisis aspek pertama untuk menemukan gambaran alienasi manusia melalui sarana (struktur) yang terdapat dalam karya sastra. Analisis aspek kedua berkaitan dengan aspek sosio-kultural yang melingkupi penciptaan karya sastra, untuk memahami gagasan-gagasan yang ada dalam novel dihubungkan dengan pandangan dunia pengarangnya.

Dalam penelitian ini kesahihan yang digunakan adalah kesahihan yang berorientasi pada data, yakni kesahihan semantik. Kesahihan semantis mengukur tingkat kesensitifan suatu teknik terhadap makna-makna simbolik yang relevan dengan konteks tertentu. Untuk mencapai derajat kehandalan, peneliti melakukan pembacaan berulang-ulang (intraratter). Dari pembacaan intensif dan berulang-ulang diharapkan dapat diperoleh hasil yang memenuhi kriteria kehandalan, dengan ditemukannya konsistensi data penelitian.

\section{Hasil Penelitian dan Pembahasan 1. Hasil Penelitian}

Penelitian ini berusaha mengungkap wujud alienasi dan unsur yang digunakan untuk menggambarkan alienasi yang terdapat dalam novel Pol karya Putu Wijaya. Alienasi sebagai salah satu tema eksistensialisme, akhir-akhir ini sering menjadi persoalan serius dalam kehidupan manusia. Menurut Darma (1995:134) alienasi manusia pada awalnya merupakan gejala sosial dalam masyarakat modern.

Untuk memahami gambaran alienasi atau keterasingan manusia dalam fiksi, dilakukan analisis terhadap tokoh utama novel Pol karya Putu Wijaya. Analisis dilakukan dengan memanfaatkan filsafat eksistensialisme, terutama pada tema alienasi atau keterasingan. Berkaitan dengan strukturt novel, untuk memahami alienasi tokoh utama, dilakukan pemahaman terhadap unsurunsur penokohan. Unsur penokohan yang dimanfaatkan untuk menganalisis wujud alienasi dalam novel Pol, yaitu (1) deskripsi pengarang tentang tokoh, (2) jalan pikiran tokoh, (3) tindakan tokoh, dan (4) reaksi tokoh lain terhadap tokoh utama. Melalui unsur penokohan tersebut dapat diidentifikasi wujud alienasi manusia. Hal itu sejalan dengan konsep dalam filsafat eksistensialisme berkenaan dengan persoalan alienasi. Ciri penanda manusia (dalam hal ini tokoh utama novel) yang mengalami alienasi tampak melalui beberapa hal, yaitu (1) sikap, (2) pola pikir, dan (3) tindakan atau tingkah laku tokoh.

Selanjutnya hasil penelitian ditampilkan dalam bentuk tabel sesuai dengan permasalahan penelitian yang telah ditetapkan. Hasil penelitian mencakup (a) wujud alienasi, dan (b) unsur penokohan yang digunakan untuk menggambarkan alienasi. Hasil penelitian ditampilkan dalam bentuk tabel sebagai berikut. 
Tabel Wujud Alienasi Tokoh dan Sarana Pengungkapannya

\begin{tabular}{|c|l|l|l|}
\hline No & Wujud Alienasi & \multicolumn{1}{|c|}{ Varian } & Unsur Penokohan \\
\hline 01 & Kesepian & $\begin{array}{l}\text { a. tidak dapat mengendalikan diri } \\
\text { b. terobsesi oleh mimpi } \\
\text { c. kegagalan membina rumah tangga } \\
\text { d. situasi dan kondisi yang asing bagi } \\
\text { dirinya }\end{array}$ & $\begin{array}{l}\text { a. Deskripsi } \\
\text { Pengarang } \\
\text { b. Pikiran tokoh } \\
\text { c. Tindakan tokoh } \\
\text { d. Reaksi tokoh lain }\end{array}$ \\
\hline 02 & Kekosongan Jiwa & $\begin{array}{l}\text { a. kegagalan memenuhi keinginan dirinya } \\
\text { b. kegagalan memenuhi keinginan orang } \\
\text { lain } \\
\text { c. ketidakberdayaan } \\
\text { persoalan hidup }\end{array}$ \\
\hline 03 & Kecemasan & $\begin{array}{l}\text { a. kalah bersaing dalam kehidupan } \\
\text { b. berhadapan dengan kekuatan besar di } \\
\text { luar dirinya } \\
\text { c. kehilangan harga diri dan kehormatan }\end{array}$ & \\
\hline
\end{tabular}

\section{Pembahasan.}

Dalam novel Pol, sebagaimana novel-novel Putu Wijaya lainnya, ditampilkan masalah yang mungkin bagi kebanyakan orang adalah masalah sepele, yaitu masalah mimpi. Setiap orang tentu pernah mengalami kejadian bermimpi. Dengan kreativitas yang tinggi masalah sederhana, yakni masalah mimpi, dapat dideskripsikan dan ditampilkan dalam kemasan cerita yang menarik. Melalui cerita mimpi itulah Putu ingin berbicara tentang tragedi kemanusiaan.

Melalui cerita tersebut Putu mengetuk kesadaran kemanusiaan, bahwa temyata manusia masih terjebak pada perilaku yang terbelenggu pada pola pikir irasional. Padahal, selama ini manusia sering mengagungkan dan menganggap dirinya sebagai manusia modem. Sebagaimana yang dikemukakan Damono (1995:ii), Putu melalui novel ini menyindir usaha manusia yang terus menerus mencari, menemukan, dan memahami diri sendiri. Apa yang disindirnya merupakan suatu kenyataan yang paradoksal. Kondisi paradoksal yang dimaksud, yakni manusia harus senantiasa menemukan identitas dirinya, pada sisi yang lain, sebenamya manusia menyadari sepenuhnya bahwa usaha itu sia-sia saja. Itulah sebabnya, hidup ini sering dianggap absurd, konyol. Membaca novel Putu ini, kita diajak untuk menertawakan diri sendiri.

Melalui tokoh Aston itulah Putu ingin menampilkan keberadaan manusia modem dengan segala permasalahan yang melingkupinya. Apa yang dialami Aston, berkaitan dengan mimpinya, terbukti dapat menggambarkan perilaku-perilaku manusia dengan kedirian masing-masing, yakni manusia-manusia modem yang mengalami kondisi keterasingan atau alienasi. Selanjutnya, diuraikan kondisi keterasingan yang digambarkan dalam novel Pol.

\section{Kesepian}

Kesepian sebagai tanda terjadinya keterasingan dalam diri individu karena manusia mengalami keterputusan dengan sesama, kehilangan kontak dengan alam serta Tuhan. Dalam pengertian ini, kesepian tidak hanya berhubungan dengan keterputusan individu dengan hal-hal kebendaan (fisik), tetapi juga kondisi kejiwaan. Oleh karena itu, makna kesepian dalam hal ini tidak secara langsung berlawanan dengan kondisi seperti keramaian, kegaduhan, dan kebisingan. Dalam kondisi keramaian 
manusia dapat mengalami "kesepian", sebaliknya dalam kondisi yang sepi manusia dapat menciptakan "keramaian" dalam dirinya.

Gambaran kesepian itulah yang dialami Aston. Mimpi Aston tentang Semar menarik perhatian panitia sebuah seminar yang akan membahas penyakit masyarakat. Panitia akhirnya sampai pada suatu keputusan untuk mengundang Aston sebagai pembicara dalam seminar tersebut. Suasana yang ramai dan riuh rendah dengan berbagai perdebatan justru menegaskan keberadaan diri Aston sebagai orang yang mengalami keterasingan. Secara individu Aston mengalami keterputusan dengan dunia luar dan kondisi yang ada di sekitarnya. Deskripsi pengarang secara langsung tentang keberadaan tokoh utama memberikan gambaran kondisi kejiwaan tokoh yang sedang mengalami keterasingan.

Sambil mengganyang suguhan kopi, kue, dan kemudian makan siang, Aston dan Ayat jatuh bangun mengikuti pembicaraan dan perdebatan yang sengit di dalam seminar. Aston tidak mengerti apa yang sedang diperbincangkan. (hlm 41)

Kegagalan Aston mulai bisa untuk memenuhi tugas sebagai kepala rumah tangga kadang-kadang menyeretnya berperilaku yang ganjil. Beban hidup yang terus menumpuk menyebabkannya menjadi orang yang tidak berharga, terutama di hadapan Wami, istrinya. Aston merasa gagal membina hubungan dengan orangorang di sekitarnya, termasuk dengan istrinya sendiri. Pada kondisi itulah sebagai individu Aston selalu terikat dan tunduk pada kemauan dan keinginan istri dan orang-orang yang ada di sekitamya. Sikap dan tindakan tersebut menegaskan adanya keterasingan dalam diri Aston, dia merasa terkucil dan sendirian.

Warni lama terisak-isak. Kemudian ia memegang kepada Aston. Menyentuh rambut pembohong itu. Betapa bebalnya, ini adalah lelaki yang mengawal hidupnya. Betatapun tak berharganya dibandingkan dengan lelaki lain (hlm 70)

Sudah sekian waktu Aston berusaha untuk bermimpi kembali. Semakin ia berusaha keras untuk bermimpi, bayangan mimpi semakin jauh meninggalkan dirinya. Semuanya tampak kosong dan lengang. Tidur baginya bukan merupakan istirahat tetapi sebagai siksaan. Dalam keadaan seperti itu aston merasakan tidak dapat lagi berkomunikasi dengan orang lain, termasuk dengan istrinya.

Keinginan Aston bermimpi sebenamya lebih didasarkan adanya desakan-desakan dari luar, dari orangorang yang menaruh harapan pada kehadiran sosok Semar. Aston berusaha memenuhi keinginan mereka, keinginan orangorang yang menyuruhnya untuk bermimpi kembali. Orang-orang yang menyuruhnya bermimpi itu adalah orangorang yang selama ini sering dijadikan tempat meminjam uang atau apa saja kebutuhan hidupnya sehari-hari.

Ketika Aston mulai bisa bermimpi kembali, muncul impian dan bayangan Semar yang sulit dimengerti. Dia melihat dirinya dikendalikan dan dirasuki oleh Semar. Aston berusaha menangkap mimpinya sendiri dan ternyata selalu gagal. Itulah yang menyebabkan dia merasa terasing dengan dirinya sendiri dan tidak dapat mengendalikan apa yang ada dalam pikirannya. Untuk sekedar mengingat mimpinya saja Aston sudah tidak mampu.

Aston berusaha mengumpulkan impiannya, tapi semuanya berserakan, tak ada ujung pangkalnya. Sulit diceritakan, tak tahu dari mana 
hams memulainya. Mungkin tak bisa diceritakan, tetapi jelas, jelas betul ia merasakan sesuatu (hlm 101)

Aston selalu terobsesi oleh mimpinya tentang Semar. Obsesinya itu menyebabkan dia tenggelam dalam pengaruh kekuatan-kekuatan yang ada di luar dirinya. Dalam kesendirian dan kesepian, pikirannya dipengaruhi oleh Semar, yang selama ini selalu diangankan bisa datang dalam mimpinya. Tindakannya dituntun oleh bayangan Semar, dan gambar-gambar Semar itu meminta Aston untuk memakannya. Sosok Semar justru tidak dapat hadir dalam mimpi-mimpi Aston, ketika dia merasa sangat membutuhkan. Dengan bermimpi itulah Aston ingin menegaskan keberadaan dirinya di tengah-tengah orang yang mencintai sekaligus yang membencinya.

Aston terkejut, buru membuka matanya. Ia mendengar seperti ada yang memanggil. Aston gelagapan bangun melihat Warni, tetapi istri dan anaknya masih pulas. Tibatiba Aston terperanjat. Ia melihat ke dinding. Salah satu gambar Semar seperti bergerak-gerak (hlm 102)

Dalam relasinya dengan orangorang di sekitarnya, Aston menemukan dirinya semakin terasing dan sendiri. Kehadiran orang-orang tersebut justru mempertegas keadaan dirinya sebagai individu yang tidak berharga. Dia berusaha mengenali satu persatu orangorang yang ada di sekitarnya. Aston mempunyai pikiran bahwa semua orang yang berbaik hati pada diri dan keluarganya ternyata menyimpan keinginan-keinginan. Aston menjadi tidak berarti hidupnya bila mengingat anak-anak dan istrinya.
Aston tersenyum. Ia tak punya apa-apa, ia hanya punya istri yang sudah lama tidak mau dijamah. Ia punya anak-anak banyak sekali, yang tidak kenal sekolah. Ia punya tukang kredit yang memburuburunya seumur hidup. Ia punya Ayat yang irinya setengah mati (hlm 105).

Puncak kesepian dan kesendirian yang dialami Aston terjadi pada saat Ayat juga mengalami peristiwa mimpi. Dan yang lebih menghebohkan, Ayat dikabarkan mimpi bertemu Tuhan. Aston semakin merenungi nasib dan merasakan betapa gagalnya hidup yang dijalani. Dalam kehidupannya yang penuh kegagalan itulah, Aston merenungi kembali nasibnya, penderitaannya, dan segala kesialan yang menimpa dirinya.

Aston merasakan tiba-tiba hidupnya lebih tidak berarti ketika Wami, istrinya, memutuskan untuk meninggalkan rumah. Dalam pikirannya menggelantung beban bagaimana harus menghidupi anakanaknya tanpa Wami. Dalam kesendirian dan kesepian itu, Aston berusaha menjadi 'bagian dari kerumunan orang yang sedang mendengarkan cerita Ayat tentang mimpi yang dialaminya. Ternyata dia tetap merasakan dirinya berada dalam kesepian, walaupun di sekitamya terjadi keramaian. Jiwanya dipenuhi perasaan sepi dan tidak mempunyai gairah hidup lagi. Bahkan, hanya bermimpi saja sudah tidak mendapatkan tempat lagi, karena Ayat juga telah bermimpi yang lebih hebat. Bila Aston bermimpi melihat Semar, Ayat bermimpi melihat Tuhan.

"Ton, ayo! Ayat mimpi lihat Tuhan!" Aston tertegun mendengar pemberitahuan itu. Ia terpesona. Ia memasang kupingnya baik-baik di seta-seta isak dan amukan istrinya 
menggasak apa saja di dalam ruangan (hlm 115)

Uraian di atas memberikan gambaran tentang sikap, pikiran, dan tindakan Aston yang menunjukkan adanya gejela keterasingan dalam wujud kesepian. Keterputusan dengan diri sendiri dan dunia luar yang dapat meyebabkan kesepain dalam diri Aston, yaitu (1) saat Aston tidak dapat mengendalikan diri karnea terobsesi mimpi, (2) kegagalan dalam membina rumah rangga, (3) berada dalam situasi dan kondisi yang asing bagi dirinya, seperti ketika Aston dan Ayat diundung menjadi pembicara seminar, dan (4) kegagalannya memenuhi keinginan sendiri dan keinginan orang lain.

\section{Kekosongan Jiwa}

Kekosongan jiwa adalah kondisi individu yang tidak mengetahui lagi apa yang diinginkannya dan tidak memiliki kekuasaan terhdap apa yang terjadi dalam kehipuannya. Dalam kondisi kejiwaan yang kosong, individu selalu mengarahkan dirinya kepada orang lain untuk mencari pegangan. Sebagai individu tidak bisa lagi mengembangkan diri untuk bertingkah laku sewajarnya.

Aston merasakan kekosongan jiwa sehingga dia berkeinginan melakukan bunuh diri agar terbebas dari problem hidup. Hidupnya penuh dengan penderitaan, tidak punya harta, utang menumpuk di mana-mana. Di lain pihak, anak-istrinya menuntut agar terpenuhi kebutuhannya, kebutuhan dasar sebagai manusia. Beban berat yang ditanggung menyebabkan Aston tidak lagi mengetahui apa yang harus diperbuat dan bagaimana konsekuensi perbuatan tersebut. Aston tidak sekadar ingin bunuh diri, tetapi punya niat jahat untuk membunuh anak dan istrinya.
Aston kemarin baru pulang dari kota, badan capek dan pikiran pegel, perut lapar dan di kantong tidak ada uang sama sekali, utang sudah menumpuk, anak-bini belum makan. Aston hampir ingin bunuh diri karena tidak kuat menahan nasib sial-sial terus (hlm 2)

Deskripsi pengarang yang menggambarkan keluarga Aston memberikan informasi tentang kondisi kejiwaan yang dialami Aston. Tindakan dan tingkah laku Aston yang selalu bertengkar dengan istrinya, menegaskan bahwa dia mengalami kekosongan jiwa. Rumah tangga Aston seakan-akan tidak pernah lepas dari kungkungan penderitaan. Akibatnya, hampir setiap saat terjadi keributan di rumah tangga itu. Keributan demi keributan itu akhimya mengundang para tetangga untuk ikut campur. Begitu seringnya pertengkaran itu terjadi, sampai dapat mengetahui secara jelas dan hafal betul apa yang terjadi di rumah tangga Aston. Tidak ada rahasia lagi dalam rumah tangga itu.

Sudah berapa kali para tetangga ikut gempar karena tengah malam dari rumah Aston memberondong suara pertengkaran. Suami istri itu memang selalu gontok-gontokkan, seluruh rahasia rumah tangganya tersingkap, tidak ada yang menarik lagi (hlm 3)

Orang yang mendengar bahwa Aston telah mimpi bertemu dengan Semar memaksanya untuk bercerita. Ketika orang-orang dengan keinginannya yang besar untuk segera tahuy cerita tentang Semar, Aston justru merasa kesulitan untuk bercerita. Dia tidak dapat segera mengingat kembali mimpinya itu.

Reaksi Warni terhadap Aston pada saat Aston bermimpi tentang Semar menggambarkan bahwa di mata Wami, 
Aston adalah orang yang tidak berharga. Wami membandingkan Aston dengan orang lain. Penyesalan Warni atas diri Aston, yang tidak sanggup menghidupi keluarganya, semakin menambah kekosongan jiwa yang dialami Aston.

Mimpi Aston tentang Semar dianggap oleh Wami hanya sekedar cara untuk menghindar dari masalahmasalah yang dihadapi. Warni melarang Aston untuk bermimpi lagi dan lebih baik bekerja, karena semua persoalan tidak selesai hanya dengan bermimpi. Ketika ada seseorang yang ingin bertemu dengan Aston, Warni melarangnya. Dalam kondisi jiwanya yang kosong, tampaknya Aston berada di bawah kekuasaan Warni.

Lain kali jangan cerita mimpi melihat Semar lagi" damprat Warni, istrinya. Aku ingin bercerai sekarang juga. Aku mau kembali ke kampung. Di sini hidup seperti tahi," kata Warni. Dahi aston berkerut. "Aku tidak mau bawa anak-anak. Kamusaja yang mengongkosi di sini. Aku Cuma minta ongkos jalan (hlm 4)

Melalui komentar tokoh terhadap dirinya, diperoleh gambaran bahwa Aston adalah orang yang mengalami banyak masalah dan selalu menemui kegagalan-kegagalan. Sebagai individu yang bebas, dia tidak mampu melakukan aktivitas untuk kepentingan sendiri maupun orang yang ada di sekitarnya.

Salah satu penyebab kondisi kejiwaan terebut, karena Aston tidak memiliki bekal hidup. Dia tidak bisa membaca dan menulis, karena tidak pemah mengenal sekolah. Dalam keadaan dirinya yang serba kekurangan itulah seringkali Aston melakukan tindakan-tindakan yang menyimpang. Tindakan yang menyimpang itu dilakukan sematasemata karena memang dia tidak tahu secara pasti harus melakukan apa dan apa akibat yang timbul setelah melakukan suatu tindakan. Kondisi itulah yang menegaskan adanya kekosongan jiwa dalam diri Aston.

"Aston itu seorang jujur, Pak. Saya belum pernah kenal dengan orang yang jujur seperti dia, meskipun kadang-kadang ia juga suka mencuri atau menipu kecil-kecilan. Sekarang dia tidak punya pekerjaan karena dia tidak bisa membaca dan tidak punya keterampilan, kata Hasan.

Dalam pikiran Aston ada kecurigaan bahwa orang-orang yang memberi sesuatu kepada keluarganya pasti ada sesuatu di balik pemberian itu. Hasan yang tiba-tiba menuyuruh anaknya mengantar kue, padahal hutang istrinya di warung Hasan masih banyak. Pal Mantri juga tiba-tiba berbuat baik dengan memberi makanan, padahal sebelimnya sulit dimintai pertolongan.

Pada dasarnya dalam diri Aston masih ada upaya untuk berpikir dalam menentukan tindakannya, tetapi semua itu tidak dapat terwujud karena adanya kekuatan-kekuatan yang lebih besar di luar dirinya. Hal itulah yang menyebabkan dia harus menerima kenyataan yang sebenamya bertentangan dengan pikirannya.

"Kata Bapak, sering-sering saja mimpi. Tapi lain kali belanja di warung saja, tidak usah ke tempat lain. Kalau perlu, biar ibu yang membeli kalau Semar mau bell beras, ya?" kata anak Hasan. Aston mengangguk, asal saja. Mulutnya penuh dengan pisang goreng. (hlm 18)

Setelah sekian lama hidupnya selalu tertekan, ada keinginan dalam diri Aston untuk sejenak melupakan penderitaan yang dialami. Ketika di tangannya ada 
uang sedikit hasil pesangon dari panitia seminar, dia memutuskan untuk tidak segera pulang. Aston pergi ke kampung sebelah dan bermain judi.

Tindakan yang dilakukan Aston tersebut tampaknya justru semakin memperjelas bahwa dalam diri Aston telah mengalami kekosongan jiwa. Dia tidak mengerti dan tidak mau berpikir apa akibat dari perbuatannya. Yang ada di benaknya barangkali hanya sekadar upaya untuk sejenak melupakan masalah-masalah yang selalu menghantui kehidupannya setiap hari.

Dengan mengantongi sekitar enam ribu lima ratus, Aston merasa tidak perlu cepat-cepat pulang. Ia cepatcepat ngacir ke kampung sebelah. Di pos ronda, beberapa anak muda berkumpul. Hampir pagi, Aston baru pulang. Uang ludes. Ketika istrinya mumcul dengan membelalakkan mata sambil menanyakkan apa yang dibawanya setelah sehari suntuk ikut seminar (hlm 48)

Aston merasakan dirinya tidak berdaya menghadapi kekua tankekuatan ang ada di hadapannya. Pada saat dia di bawa ke kantor polisi dan temyata salah tangkap. Saat dia dibawa Ayat menghadap Pak Matri untuk minta maaf, karena istrinya telah menuduh Pak Mantri. Aston menurut saja apa yang diperintahkan orang orang dan tidak mau berpikir apa yang seharusnya dilakukannya. Termasuk ketika disuruh Warni menemui mantan Bosnya sekadar mengucapkann bela sungkawa. Setelah dia menyatakan penyesalan dan bela sungkawa, temyata Aston justru dimarahi dan dipukuli.

"Aston mimpi melihat Semar begitu. Itu salah. Apa salahnya mimpi lihat semar, Pak? Aston ditampar. Mata Aston ditatap dengan tajam, tetapi Aston menunduk, ia memandang dengan pandangan jujur, polos, dan menyerah (hlm 54)
Setelah semua orang selalu bertanya-tanya tentang mimpi Aston, Warni merasakan bahwa mimpi Aston juga membawa berkah bagi kehidupan keluarganya. Orang-orang yang mengharapkan Aston bermimpi lagi tentang Semar, berusaha menarik perhatian dengan memberi sesuatu kepada Warni. Oleh karena itu, Warni terpaksa ikut-ikutan memaksa Aston untuk bisa bermimpi lagi melihat Semar. Aston mengerti bahwa semua itu sebenarnya bukan kemauan Warni sendiri, tetapi Wami mencoba mengerti dan menangkap maksud dari orangorang yang ada di sekitamya.

Ketika anak-anak sudah tidur, Warni menggoyang-goyang tubuh Aston.

$$
\begin{aligned}
& \text { pi" "Kamu sudah lama tidak mim- } \\
& \text { "kamu hams mimpi lagi. Semua } \\
& \text { sudah tanya. Semua, untung belum } \\
& \text { marah, tapi sudah nyindir-nyindir." } \\
& \text { Kata Warni. }
\end{aligned}
$$

Aston sangat merasakan adanya keterputusan dengan diri sendiri dan dengan sesamanya. Dia tidak mampu lagi memahami tindakannya sendiri, sementara orangorang yang ada di sekitamya selalu mengharapkan dia untuk bermimpi tentang Semar. Itulah yang membebani pikirannya. Beban berat yang ditanggungnya membuat dia semakin tidak berdaya. Aston terus berusaha untuk dapat bermimpi. Semakin keras dia berusaha ternyata tidurnya semakin kosong tak bermakna. Ia menjadi risau dan bahkan jarang dan takut tidur.

Sekali waktu, Aston memang melonjak dari tidurnya karena desakan tiba-tiba. Ia merasakan tidak kuat, ingin lari dan pergi. Semua kasih sayang yang memancar dari jauh itu makin lama makin tidak berguna. Palsu. Bahkan hanya mem- 
buatnya bertambah terbungkukbungkuk (hlm 85)

Hubungan dengan istrinya semakin tidak baik karena masalah kehidupan sehari-hari. Istrinya selalu marah-marah dan menuntut agar Aston dapat memenuhi kebutuhan keluarga. Pada saat kondisi kejiwaan tertekan, Aston tidak mampu mengendalikan dirinya dan tiba-tiba dia menempeleng Wami. Hal itu diakukan bukan karena kebenciannya kepada Wami, tetapi disebabkan kondisi kejiwaan yang kosong sehingga tidak mengerti harus melakukan apa-apa.

"Aku sudah jengkel. Aku tidak mau lagi menanggung sekarang. Aku mau minggat saja. Aku pulang sekarang, akau bawa yang kecil. Biar mampus sendiri di sini, biar kamu rasa in bagaimana caranya. Aku tidak mau ringsek di sini" (hlm 114)

Dalam kondisi kebingungan itulah timbul suatu keinginan agar bisa terlepas dari beban hidup. Salah satu yang dianggap membebani adalah utangnya pada tukang kredit. Timbullah keinginan untuk menghabisi tukang kredit itu agar hari-harinya tidak selalu diburuburu. Dia berpikir dengan melakukan itu beban hidupnya akan sedikit terkurangi.

Dalam keadaan kepepet tubuhnya menolong memberi jalan keluar yang terakhir. Setelah mondarmandir is meraih pisau dapur, menyembunyikannya di belakang pinggangnya, lalu menunggu. Di dengarnya langkah yang begitu dikenalnya menghampiri. Terasa juga olehnya beban di pundak kiri tukang kredit itu, tas yang berisi catatan (hlm 118)

Uraian di atas memberikan gambaran tentang keterasingan yang dialami
Aston yang akhimya memunculkan sikap, pikiran, dan tindakan yang menandai adanya kekosongan jiwa. Kekosongan jiwa yang dialami Aston karena dia tidak memiliki kekuatan dan kekuasaan untuk menghadapi persoalan. Hal itu antara lain tampak pada, (1) ketidakberdayaan menghadapi persoalan kehidupan keluarga, (2) keinginan orangorang tentang mimpinya, (3) kegagalan menjadi kepala rumah tangga sehingga hams tunduk pada istrinya, (4) berhadapan dengan kekuatan-kekuatan besar dari luar, seperti Pak RT, Pak Mantri, Petugas, dan mantan Bosnya. Hal-hal di atas itulah yang menyebabkan Aston tidak dapat menempatkan dirinya sebagai subjek atas perilakunya sendiri. Ketidakberdayaan untuk menjadikan dirinya sebagai subjek menyebabkan dia selalu terseret oleh kekuatan yang deterministik yang berasal dari luar dirinya.

\section{Kecemasan}

Dalam pandangan eksistensialisme, kecemasan dianggap sebagai masalah yang lebih serius dibandingkan dengan kesepian dan kekosongan jiwa. Kecemasan yang memuncak dapat mengancam eksistensi individu, karena sebagai individu sudah tidak mengetahui peran apa yang harus dijalankan. Persaingan hidup yang semakin ketat menyebabkan manusia mengalami kecemasankecemasan.

Sikap, pikiran, dan tindakan tokoh Aston menampakkan adanya kecmasan dalam dirinya. Dia merasa cemas bila bertemu dengan orang lain, seperti Hasan, Ceu Epon, dan tukang kredit. Semua itu karena Aston dan istrinya banyak berhutang pada mereka. Aston tidak bisa segera melunasi hutang-hutangnya. Hutanghutang itu menjadi beban pikirannya dan menimbulkan kecemasan dalam dirinya.

Aston menjilat bibirnya yang berminyak. Matanya melirik ke war- 
ung Hasan. Kebetulan Hasan juga sedang memandang kepadanya dengan melotot. Aston cepat-cepat membuang muka dan mengatupkan mulutnya, karena teringat hutang-hutangnya masih bertumpuktumpuk di tempat hasan. (hlm 10)

Aston tidak tahu harus berbuat apa ketika mendengar kabar kematian anak mantan Bosnya. Dia mendengar kabar itu dari Wami dan ternyata kejadiannya itu sudah satu tahun yang lalu. Warni memaksa Aston untuk segera pergi menemui majikan untuk sekedar ikut bela sungkawa. Aston merasa khawatir bila kemunculannya itu ditafsirkan bahwa ia ingin minta pekerjaan. Sebenarnya Aston menyadari bahwa ia butuh pekerjaan untuk menghidupi anak istrinya. Akan tetapi, ada rasa khawatir bila harus meminta-minta pekerjaan pada orang yang dulu telah memecatnya. Dia masih mempunyai pertimbangan harga diri, walaupun nyatanya tidak dapat dipertahankan.

Aston bukannya tak mau pergi, ia hanya khawatir kalau unjuk muka ke situ, jangan-jangan disangka mau minta kerjaan. Tetapi soalnya ia segan untuk kerja. (hlm 61)

Aston mengalami kecemasan yang memuncak saat dia berusaha untuk bermimpi lagi. Aston berpikir bahwa ia akan kehilangan semua impiannya. Dia merasa takut kalau hanya untuk bermimpi sja sudah tidak bisa lagi. Dalam kekhawatirannya itu sampai dia menyuruh Boy, anaknya, untuk turut bermimpi. Boy dipaksa Aston untuk bermimpi tentang Semar.

Aston sering termenung setelah terbangun, karena mencoba mencari-cari, masa tidak ada sedikitpun yang dialaminya. Lama-lama ia jadi takut juga kalau semua impiannya hilang.. (hlm 93)
Uraian di atas memberi gambam kondisi kejiwaan Aston yang mengalami kecemasan. Kecemasan itu muncul antara lain karena, (1) Aston kalah bersaing dalam kehidupan yang keras, (2) kehilangan harga diri di hadapan istrinya, dan (3) ketidaktahuannya harus melakukan tindakan apa untuk menyelesaikan persoalan yang dihadapinya.

\section{Simpulan dan Saran \\ 1. Simpulan}

Berdasarkan hasil penelitian dan analisis yang dilakukan dapat disimpulkan beberapa hal sebagai berikut.

1) Alienasi atau keterasingan dalam novel Pol dari aspek wujudnya dikelompokkan dalam tiga klasifikasi, yaitu (a) kesepian, (b) kekosongan jiwa, dan (c) kekecewaan.

2) Gejala alienasi tokoh ditampilkan oleh pengarang melalui unsur penokohan, yaitu (1) deskripsi pengarang tentang tokoh, (2) jalan pikiran tokoh, (3) tindakan tokoh, dan (4) reaksi tokoh lain terhadap tokoh utama.

\section{Saran}

Penelitian yang mengungkapkan tentang wujud alienasi dalam novel Pol ini masih terbatas pada kajian yang bersifat struktural semiotik. Oleh karena itu, masih sangat terbuka kemungkinan untuk melakukan kajian lebih lanjut, khususnya yang diarahkan pada masyarakat pembaca. Kajian dapat dilakukan dengan memanfaatkan pendekatan resepsi sastra. Dengan demikian, akan diketahui tanggapan masyarakat terhadap wujud alienasi yang ditampilkan dalam novel tersebut.

\section{Daftar Pustaka}

Dagun, Save M. 1990. Filsafat Eksistensialisme. Jakarta: Rineka Cipta 
Darma, Budi. 1995. Harmonium. Yogyakarta: Penerbit Pustaka Pelajar

Damono, Sapardi Djoko. 1984. Sosilogi Sastra, Sebuah Pengantar Ringkas. Jakarta: Depdikbud. 1995. "Menegur Diri Sendiri". Pengantar Novel Byar Pet. Jakarta: Pustaka Firdaus.

Drijarkara. 1995. Percikan Filsafat. Jakarta: PT Pembangunan

Goldman. Lucien. 1973. “The Sociology of Literature: Status amd Problem Method" dalam The Sociology of Art and Literature. Milton C. Albrecht, ed. New York: Praeger Publication.

Hasan, Fuad. 1992. Berkenalan dengan Eksistensialisme. Jakarta: Pustaka Jaya.
Koeswara, E. 1987. Psikologi Eksistensialis: Suatu Pengantar. Bandung: Penerbit Eresco.

Kuntowijoyo. 1984. Penokohan dan Perwatakan dalam Sastra Indonesia. Dalam Budaya Sastra. Andy Zoeltom (Ed.) Jakarta: Penerbit Radjawali.

Poespowardojo, Soerjanto. 1989. Strategi Kebudayaan Suatu Pengantar Filosofis. Jakarta: Penerbit Gramedia.

Suyitno. 1996. Sastra Tata Nilai dan Eksesgesis. Yogyakarta: Penerbit Hanindita.

Wellek, Rene dan Austin Wareen. 1990. Teori kesustraan. Terjemahan Melani Budianta. Jakarta: Penerbit Gramedia. 